\title{
APLIKASI PROGRAM LINIER INTEGER 0-1 UNTUK MENYUSUN JADWAL USULAN PIKET SATPOL PP
}

\section{Integer 0-1 Linier Programming Application for Preparing a Satpol PP Packet Schedule}

\author{
Koko Hermanto ${ }^{1 *}$, Ryan Suarantalla ${ }^{2}$, Sahdan $^{3}$ \\ 1,2,3 Teknik Industri, Fakultas Teknik, Universitas Teknologi Sumbawa \\ Jl. Raya Olat Maras ds. Batu Alang Kec. Moyo Hulu Kab. Sumbawa NTB, 84371, Indonesia \\ e-mail: 1*koko.hermanto@uts.ac.id ; 2 ryansuarantalla@uts.ac.id ; 3 supu.syahdan@gmail.com ; \\ Corresponding author*
}

\begin{abstract}
Abstrak
Program linier integer nol-satu dengan pendekatan software Lindo dapat digunakan untuk menyelesaikan persoalan metode penjadwal siklis. Metode penjadwalan siklis salah satu metode penjadwalan yang dapat digunakan untuk menjadwalkan piket kerja Satuan Polisi Pamong Praja (Satpol PP), dimana masing-masing Satpol PP akan bekerja dalam jangka waktu tertentu yaitu 5 hari dan akan berulang secara periodik. Solusi variabel keputusan dari model program liniernya yaitu nol atau satu yang menjadi keputusan Satpol PP dalam memilih tipe jadwal. Penyusunan jadwal usulan ini memperhatikan bobot kesukaan hari libur Satpol PP di setiap tipe jadwal yang dibentuk sehingga fungsi tujuan dari model program liniernya adalah memaksimumkan bobot kesukaan hari libur setiap Satpol PP terhadap tipe jadwal yang ada. Hasil analisa diperoleh jadwal usulan yang optimal dalam memaksimumkan kualitas penugasan di setiap shift dengan tetap memperhatikan beban dan kendala kerja yang ada. Selain itu juga diketahui bahwa perbandingan antara penjadwalan usulan dengan penjadwalan yang selama ini digunakan terlihat pada aspek kualitas dan keadilan penjadwalan yang dilakukan di penjadwalan usulan lebih unggul.
\end{abstract}

Kata Kunci : Penjadwalan siklis, Program linier integer 0-1, Lindo, Satpol PP.

\begin{abstract}
A zero-one integer linear programming with the Lindo software approach can be used to solve the cyclical scheduler method problem. The cyclical scheduling method is one of the scheduling methods that can be used to schedule work picks from Satuan Polisi Pamong Praja (Satpol PP), where each Satpol PP will work within a specified period of 5 days and will repeat periodically. The decision variable solution to the linear programming model is zero or one which becomes the decision of the Satpol PP in choosing the type of schedule. The preparation of this proposed schedule pays attention to the preferred weight of the Satpol PP holidays in each type of schedule that is formed so that the objective function of the linear programming model is to maximize the preferred holiday weights per Satpol PP against the existing schedule types. The results of the analysis obtained an optimal proposal schedule in maximizing the quality of assignments to each shift while taking into account the workload and constraints that exist. Also, it is known comparison between proposal scheduling and scheduling that has been used so far is seen in the aspect of quality, and fairness of the schedule carried out in the proposed scheduling is superior.
\end{abstract}

Keywords: Cyclic scheduling, linear integer program 0-1, Lindo, Satpol PP. 


\section{PENDAHULUAN}

Satpol PP merupakan salah satu perangkat pemerintah daerah yang berperan penting bagi suatu daerah dalam memelihara kebersihan, keindahan dan ketertiban serta menegakkan keamanan bagi masyarakat, hal ini Berdasarkan Pasal 148 Undang-Undang Nomor 23 Tahun 2014 tentang Pemerintah Daerah serta Peraturan Pemerintah Nomor 32 Tahun 2004 tentang Pedoman Satuan Polisi Pamong Praja. Satpol PP sangat dibutuhkan oleh pemerintah daerah keberadaannya, dikarenakan Satpol PP memiliki tugas dan fungsi dalam rangka memelihara ketentraman dan menyelenggarakan ketertiban umum (trantibum) serta menegakkan produk hukum daerah (Perda) dan Peraturan Kepala Daerah merupakan salah satu komponen penegak hukum yang sangat penting [1].

Berdasarkan surat Peraturan Pemerintah Republik Indonesia Nomor 6 Tahun 2010 bahwa dalam rangka mewujudkan kinerja aparatur yang optimal, dalam meningkatkan ketertiban umum dan perlindungan masyarakat serta pelaksanaan reformasi birokrasi di lingkungan pemerintah Kabupaten, perlu adanya standar operasional prosedur penyelengaraan tugas-tugas administrasi pemerintahan pada Satpol PP khususnya di Kabupaten Sumbawa.

Guna memenuhi harapan dari masyarakat dalam upaya perlindungan serta ketertiban, merupakan tantangan tersendiri bagi kelembagaan pemerintah daerah, khususnya Satpol PP itu sendiri dalam memenuhi tugas pokok serta fungsinya secara optimal, maka perlu didukung oleh kualitas sumber daya optimal, anggaran operasional dan sarana prasarana Satpol PP yang memadai.

Pemeliharaan ketertiban umum, ketentraman masyarakat dan perlindungan masyarakat suatu daerah salah satunya dipengaruhi oleh pelayanan yang diberikan Satpol PP bagi masyarakat. Kenyataan yang ditemui di lapangan, pada bagian penjagaan masih terlihat rendah karena masih ada beberapa anggota Satpol PP yang meninggalkan pos jaga saat jam kerja berlangsung. Hal ini disebabkan karena adanya keperluan pribadi yang menyebabkan anggota Satpol PP meningalkan pos jaga saat jam kerja berlangsung. Untuk mengatasi masalah ini peneliti menyusun jadwal shift kerja usulan Satpol PP yang sesuai dengan optimalisasi bobot kesukaan libur anggota Satpol PP, harapannya anggota Satpol PP dapat menjalankan tugasnya dengan optimal pada jadwal dinas kerjanya.

Penyusunan jadwal menggunakan program linier integer 0-1 telah dilakukan penelitian sebelumnya yang dilakukan oleh [2], [3] dan [4], dimana penyusunan jadwal pada penelitian tersebut adalah menyusun jadwal usulan perawat rumah sakit. Adapun pola shift kerja yang diterapkan pada perawat rumah sakit adalah pagi, pagi, siang, siang, malam, malam, libur, libur (P-P-S-S-M-M-L-L). Sehingga dari tipe jadwal tersebut dapat disusun kombinasi tipe-tipe jadwal baru secara siklik. Pada penelitian ini, peneliti mencoba menerapkan program linier integer 0-1 untuk menyusun jadwal usulan pada petugas Satpol PP. Menyusun jadwal usulan Satpol PP Kabupaten Sumbawa dengan menggunakan metode program linier integer 0-1, selanjutnya menggunakan software Lindo untuk menyelesaikan model program linier integer 0-1 yang disusun tersebut. Adapun fungsi tujuan dari program linier yang dibentuk adalah mengoptimalkan bobot kesukaan hari libur anggota Satpol PP dengan memperhatikan beberapa kendala, yaitu tipe jadwal, penentuan hari liburnya dan penentuan jumlah Satpol PP tiap shift, sehingga dari model program linier integer 0-1 yang disusun tersebut diperoleh hasil keputusan setiap anggota Satpol PP yaitu 0 atau 1. Sehingga mempermudah peneliti untuk menetapkan tipe jadwal pada satpol PP yang bersangkutan untuk memilih tipe jadwal dari solusi yang diperoleh. Dimana, saat solusi variabel keputusan bernilai 0 maka Satpol PP tidak memilih tipe jadwal yang ditetapkan tersebut, jika solusi nilai variabel keputusan bernilai 1 maka Satpol PP memilih tipe jadwal yang ditetapkan tersebut.

Aplikasi program linier integer 0-1 selain diaplikasikan pada penyusunan jadwal seperti penelitian yang juga telah dilakukan oleh [5], [6] dan [7]. Selain itu, dapat juga diaplikasikan pada kasus-kasus yang lain seperti dalam pengambilan dua keputusan seperti penelitian yang dilakukan oleh [8] berupa keputusan dalam pemilihan media periklanan, serta penentuan rute terpendek seperti yang dilakukan oleh [9] dan [10]. Selain itu, penelitian yang dilakukan oleh [11] mengaplikasikan program linier integer 0-1 dalam strategi menyelesaikan masalah penyimpanan serta dapat juga diaplikasikan dalam masalah optimasi produksi seperti yang dilakukan oleh [12]. 


\section{METODE PENELITIAN}

\subsection{Data}

Data yang diperlukan untuk penyusunan jadwal usulan piket Satpol PP menggunakan program linier integer 0-1 pada bidang Ketertiban Umum dan Ketentraman Masyarakat (KIBUM) kelompok I adalah sebagai berikut:

1. Data jumlah anggota pada bidang KIBUM kelompok I, minimal jumlah anggota yang bertugas setiap shift.

2. Jadwal tugas Satpol-PP bidang KIBUM kelompok I pada bulan September 2018.

3. Metode jadwal yang selama ini diterapkan pada bidang KIBUM kelompok I, yaitu metode penjadwalan yang dilakukan adalah metode penjadwalan siklis dimana setiap anggota-anggota Satpol PP akan bekerja selama satu periode jadwal yang terdiri 5 hari yaitu mengikuti pola shift berikut yaitu pagi, malam, libur, libur, siaga (P-M-L-L-Siaga) dilanjutkan dengan periode-periode selanjutnya dengan pola shift yang sama.

4. Bobot kesukaan libur setiap anggota Satpol PP pada hari Senin Sampai hari Minggu, diperoleh dari kuesioner yang dilakukan ke setiap Satpol PP bidang KIBUM kelompok I. Adapun contoh tabel pada form kuesioner dapat dilihat pada Tabel 1 berikut.

Tabel 1. Kuesioner bobot kesukaan libur

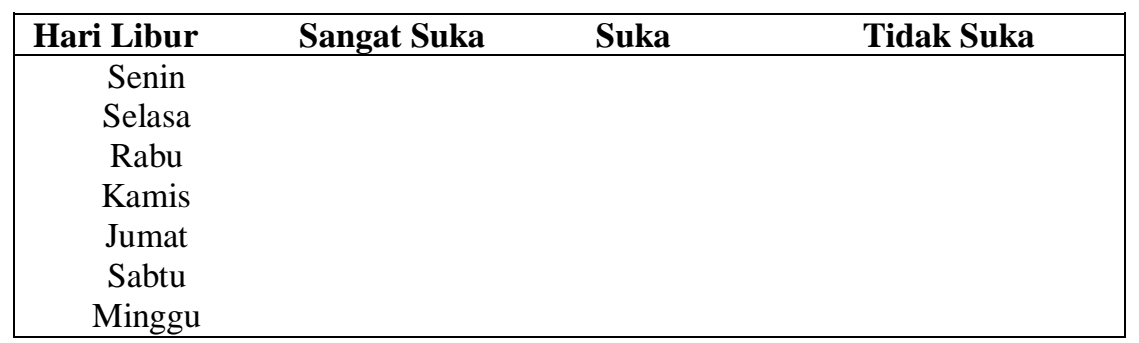

\subsection{Teknik Analisis Data}

Teknik analisis data untuk menyusun jadwal tugas Satpol PP pada bidang KIBUM kelompok I pada bulan September 2018 menggunakan program linier integer nol-satu adalah sebagai berikut.

1. Menyusun kombinasi tipe jadwal yang biasa dibentuk dan dapat diterapkan pada jadwal Satpol dari tipe jadwal yang selama ini digunakan.

2. Dari data kuesioner yang telah diperoleh, ditentukan bobot masing-masing tipe jadwal setiap periode.

3. Menyusun model matematika program linier integer nol-satu.

4. Menyelesaikan model program linier intger nol-satu menggunakan software Lindo.

5. Menginterprestasikan solusi model program linier integer nol-satu untuk menyusun jadwal tugas anggota Satpol PP bidang KIBUN kel ompok I pada bulan September 2018.

\section{HASIL DAN PEMBAHASAN}

\subsection{Tipe-tipe Jadwal}

Terdapat 5 tipe jadwal yang dapat disusun untuk menyusun jadwal usulan dari tipe yang selama ini digunakan oleh anggota Satpol PP. ke-5 tipe jadwal tersebut disajikan pada Tabel 2.

Tabel 2. Tipe Jadwal dalam Satu Priode

\begin{tabular}{|cccccc|}
\hline \multirow{2}{*}{ Tipe Jadwal } & \multicolumn{5}{c|}{ Hari } \\
\cline { 2 - 6 } & $\mathbf{1}$ & $\mathbf{2}$ & $\mathbf{3}$ & $\mathbf{4}$ & $\mathbf{5}$ \\
\hline A & P & M & L & L & Siaga \\
B & M & L & L & Siaga & P \\
C & L & L & Siaga & P & M \\
D & Siaga & P & M & L & L
\end{tabular}




\begin{tabular}{|ccccccc|}
\hline \multirow{2}{*}{ Tipe Jadwal } & \multicolumn{5}{c|}{ Hari } \\
\cline { 2 - 6 } & $\mathbf{1}$ & $\mathbf{2}$ & $\mathbf{3}$ & $\mathbf{4}$ & $\mathbf{5}$ \\
\hline E & L & Siaga & P & M & L \\
\hline
\end{tabular}

Diketahui dalam satu periode jadwal ada 5 hari maka ada 7 jenis periode yang diperoleh untuk menyusun jadwal susulan Satpol PP yaitu Periode 1 ( Senin-Jumat), Periode 2 (Selasa-Sabtu), periode 3 (Rabu-Minggu), periode 4 (Kamis-Senin), periode 5 (Jumat-Selasa), Periode 6 (Sabtu-Rabu), periode 7 (Minggu-Kamis).

\subsection{Bobot Tipe-tipe Jadwal}

Bobot kesukaan libur anggota Satpol PP pada hari Senin-Minggu diperoleh dengan melakukan pengisian angket kuesioner oleh 10 anggota Satpol PP pada bidang KIBUM. Kesukaan libur dibagi menjadi 3 kelas interval yaitu 'sangat suka' diberikan bobot 5, 'suka' diberikan bobot 3, sedangkan 'tidak suka' diberikan bobot 1. Karena jadwal yang akan diusulkan yaitu jadwal pada bulan September 2018 maka harus diketahui bobot kesukaan libur Satpol PP terhadap tipe jadwal pada periode 6 (Sabtu-Rabu) karena pada bulan tersebut diawali dengan hari Sabtu, kemudian periode 3 (Kamis-Senin) karena pada periode 6 diakhiri dengan hari Kamis dan seterusnya. Pada Tabel 3 disajikan total bobot kesukaan libur Satpol PP dalam satu periode (masing-masing terdapat 2 hari libur) yang diperoleh dari hasil kuesioner dan penentuan hari libur berdasarkan tipe-tipe jadwal pada Tabel 2.

Tabel 3. Bobot kesukaan libur Satpol PP terhadap tipe Jadwal

\begin{tabular}{|c|c|c|c|c|c|c|c|c|c|}
\hline No & Nama & $\begin{array}{c}\text { Tipe } \\
\text { Jadwal }\end{array}$ & $\begin{array}{l}\text { Senin- } \\
\text { Jumat }\end{array}$ & $\begin{array}{c}\text { Sabtu- } \\
\text { Rabu }\end{array}$ & $\begin{array}{c}\text { Kamis- } \\
\text { Senin }\end{array}$ & $\begin{array}{l}\text { Selasa- } \\
\text { Sabtu }\end{array}$ & $\begin{array}{c}\text { Minggu } \\
\text {-Kamis }\end{array}$ & $\begin{array}{l}\text { Jumat- } \\
\text { Selasa }\end{array}$ & $\begin{array}{l}\text { Rabu- } \\
\text { Minggu }\end{array}$ \\
\hline \multirow{5}{*}{1.} & \multirow{5}{*}{ Drs. M. Nukman } & A & 6 & 6 & 2 & 8 & 6 & 4 & 6 \\
\hline & & $\mathrm{B}$ & 6 & 4 & 6 & 6 & 6 & 2 & 8 \\
\hline & & $\mathrm{C}$ & 6 & 2 & 8 & 6 & 4 & 6 & 6 \\
\hline & & $\mathrm{D}$ & 8 & 6 & 4 & 6 & 6 & 6 & 2 \\
\hline & & $\mathrm{E}$ & 8 & 4 & 6 & 4 & 4 & 8 & 4 \\
\hline \multirow{5}{*}{2.} & \multirow{5}{*}{ M. Ramli Saputra } & $\mathrm{A}$ & 10 & 10 & 10 & 10 & 10 & 10 & 10 \\
\hline & & $\mathrm{B}$ & 10 & 10 & 10 & 10 & 10 & 10 & 10 \\
\hline & & $\mathrm{C}$ & 10 & 10 & 10 & 10 & 10 & 10 & 10 \\
\hline & & $\mathrm{D}$ & 10 & 10 & 10 & 10 & 10 & 10 & 10 \\
\hline & & $\mathrm{E}$ & 10 & 10 & 10 & 10 & 10 & 10 & 10 \\
\hline \multirow{5}{*}{3.} & \multirow{5}{*}{ Abadiono } & $\mathrm{A}$ & 8 & 6 & 2 & 10 & 6 & 4 & 6 \\
\hline & & $\mathrm{B}$ & 6 & 4 & 6 & 8 & 6 & 2 & 0 \\
\hline & & $\mathrm{C}$ & 6 & 2 & 10 & 6 & 4 & 6 & 8 \\
\hline & & $\mathrm{D}$ & 10 & 6 & 4 & 6 & 8 & 6 & 2 \\
\hline & & $\mathrm{E}$ & 8 & 4 & 8 & 4 & 6 & 8 & 4 \\
\hline \multirow{5}{*}{4.} & \multirow{5}{*}{ Hamzah } & $\mathrm{A}$ & 10 & 10 & 2 & 10 & 10 & 6 & 8 \\
\hline & & $\mathrm{B}$ & 10 & 6 & 6 & 10 & 6 & 2 & 10 \\
\hline & & $\mathrm{C}$ & 10 & 2 & 10 & 10 & 10 & 6 & 8 \\
\hline & & $\mathrm{D}$ & 10 & 10 & 6 & 6 & 10 & 10 & 6 \\
\hline & & $\mathrm{E}$ & 10 & 6 & 10 & 6 & 6 & 10 & 6 \\
\hline \multirow{5}{*}{5.} & \multirow{5}{*}{ Abdurrachman } & $\mathrm{A}$ & 8 & 6 & 6 & 10 & 6 & 6 & 8 \\
\hline & & B & 6 & 6 & 8 & 8 & 6 & 6 & 10 \\
\hline & & $\mathrm{C}$ & 6 & 6 & 10 & 6 & 6 & 8 & 8 \\
\hline & & $\mathrm{D}$ & 10 & 6 & 6 & 8 & 8 & 6 & 6 \\
\hline & & $\mathrm{E}$ & 8 & 6 & 8 & 6 & 8 & 8 & 6 \\
\hline \multirow{3}{*}{6.} & \multirow{3}{*}{ Ryan Soneta } & A & 8 & 6 & 2 & 10 & 6 & 4 & 6 \\
\hline & & B & 6 & 4 & 6 & 8 & 6 & 2 & 10 \\
\hline & & $\mathrm{C}$ & 6 & 2 & 10 & 6 & 4 & 6 & 8 \\
\hline
\end{tabular}




\begin{tabular}{|c|c|c|c|c|c|c|c|c|c|}
\hline No & Nama & $\begin{array}{c}\text { Tipe } \\
\text { Jadwal }\end{array}$ & $\begin{array}{l}\text { Senin- } \\
\text { Jumat }\end{array}$ & $\begin{array}{c}\text { Sabtu- } \\
\text { Rabu }\end{array}$ & $\begin{array}{c}\text { Kamis- } \\
\text { Senin }\end{array}$ & $\begin{array}{c}\text { Selasa- } \\
\text { Sabtu }\end{array}$ & $\begin{array}{c}\text { Minggu } \\
\text {-Kamis }\end{array}$ & $\begin{array}{l}\text { Jumat- } \\
\text { Selasa }\end{array}$ & $\begin{array}{l}\text { Rabu- } \\
\text { Minggu }\end{array}$ \\
\hline & & $\mathrm{D}$ & 10 & 6 & 4 & 6 & 8 & 6 & 2 \\
\hline & & $\mathrm{E}$ & 8 & 4 & 8 & 4 & 6 & 8 & 4 \\
\hline \multirow{5}{*}{7.} & \multirow{5}{*}{ Juli Fitriadi, S. Ap } & $\mathrm{A}$ & 6 & 6 & 6 & 8 & 6 & 6 & 8 \\
\hline & & B & 6 & 6 & 8 & 6 & 6 & 6 & 8 \\
\hline & & $\mathrm{C}$ & 6 & 6 & 8 & 6 & 6 & 8 & 6 \\
\hline & & D & 8 & 6 & 6 & 8 & 6 & 6 & 6 \\
\hline & & $\mathrm{E}$ & 8 & 6 & 6 & 6 & 6 & 8 & 6 \\
\hline \multirow{5}{*}{8.} & \multirow{5}{*}{ Nahudidin } & $\mathrm{A}$ & 4 & 6 & 10 & 2 & 6 & 8 & 6 \\
\hline & & B & 6 & 8 & 6 & 4 & 6 & 10 & 2 \\
\hline & & $\mathrm{C}$ & 6 & 10 & 2 & 6 & 8 & 6 & 4 \\
\hline & & D & 2 & 6 & 8 & 6 & 4 & 6 & 10 \\
\hline & & $\mathrm{E}$ & 4 & 8 & 4 & 8 & 6 & 4 & 8 \\
\hline \multirow{5}{*}{9.} & \multirow{5}{*}{ Hermansyah } & $\mathrm{A}$ & 4 & 6 & 2 & 2 & 6 & 4 & 2 \\
\hline & & B & 6 & 4 & 2 & 4 & 6 & 2 & 2 \\
\hline & & $\mathrm{C}$ & 6 & 2 & 2 & 6 & 4 & 2 & 4 \\
\hline & & $\mathrm{D}$ & 2 & 6 & 4 & 2 & 4 & 6 & 2 \\
\hline & & $\mathrm{E}$ & 4 & 4 & 4 & 4 & 2 & 4 & 4 \\
\hline \multirow{5}{*}{10.} & \multirow{5}{*}{ Kaharudin } & A & 10 & 10 & 2 & 10 & 10 & 6 & 6 \\
\hline & & B & 10 & 6 & 6 & 10 & 10 & 2 & 10 \\
\hline & & $\mathrm{C}$ & 10 & 2 & 10 & 10 & 6 & 6 & 10 \\
\hline & & $\mathrm{D}$ & 10 & 10 & 6 & 6 & 10 & 10 & 2 \\
\hline & & $\mathrm{E}$ & 10 & 6 & 10 & 6 & 6 & 10 & 6 \\
\hline
\end{tabular}

\subsection{Model Program Linier Integer 0-1}

Penyusunan jadwal menggunakan program linier integer 0-1 telah dilakukan penelitian sebelumnya untuk menyusun jadwal perawat yang dilakukan oleh [2], [3], dan [4]. Berdasarkan penelitian tersebut untuk menyusun model program linier integer 0-1 ada beberapa variabel yang digunakan untuk menyusun jadwal usulan Satpol PP, yaitu:

$\mathrm{Z}$ = nilai fungsi tujuan, memaksimumkan bobot kesukaan hari libur Satpol PP terhadap tipe jadwal.

$\mathrm{i} \quad=1,2, \ldots, \mathrm{n}$ (anggota Satpol PP yang akan dijadwalkan)

$\mathrm{k} \quad=$ kode tipe jadwal

$\mathrm{n} \quad=$ Satpol PP terakhir yang dijadwalkan.

$\mathrm{C}_{\mathrm{ik}}=$ bobot kesukaan hari libur anggota Satpol PP ke-i dengan tipe jadwal $\mathrm{k}$.

$\mathrm{X}_{\mathrm{ik}}=$ bernilai 1 apabila Satpol PP i masuk dinas dengan tipe jadwal k, bernilai 0 jika tidak memilih Tipe jadwal k.

$\mathrm{Q}_{\mathrm{k}}=$ jumlah Satpol PP minimum yang dibutuhkan pada posjaga dengan tipe jadwal $\mathrm{k}$

Fungsi tujuan:

$$
\mathrm{Z}=\max \sum_{\mathrm{i}=1}^{\mathrm{n}} \sum_{\mathrm{k}=1}^{\mathrm{k}} \mathrm{C}_{\mathrm{ik}} \mathrm{X}_{\mathrm{ik}}
$$

Tujuannya yang ingin dicapai adalah memaksimalkan bobot kesukaan libur anggota Satpol PP. 
Fungsi kendala:

Tiap Satpol PP hanya biasa ditugaskan pada salah satu tipe jadwal.

$$
\sum_{\mathrm{k}=1}^{\mathrm{k}} \mathrm{X}_{\mathrm{ik}}=1
$$

Untuk $\mathrm{i}=1,2, \ldots, \mathrm{n}$ anggota Satpol PP yang ditugaskan di pos jaga.

Jumlah Anggota Satpol PP harus sama atau lebih besar dari jumlah perawat yang dapat dijadwalkan dengan tipe jadwal $\mathrm{k}$.

$$
\sum_{\mathrm{i}=1}^{\mathrm{n}} \mathrm{X}_{\mathrm{ik}} \geq \mathrm{Q}_{\mathrm{k}}
$$

Diketahui $\mathrm{Q}_{\mathrm{k}}=2$ untuk setiap bidang.

Dari hasil pengolahan model program liniear intiger nol-satu maka dapat disusun jadwal usulan untuk bulan September 2018, dimana pada bulan tersebut diawali dengan hari Sabtu maka penyusunan jadwal diawali dengan menggunakan hasil dari periode 6 (Sabtu-Rabu) diikuti periode 4 (Kamis-Senin), periode 2 (Selasa-Sabtu), Periode 7 (Minggu-Kamis), Periode 5 (Jumat-Selasa) dan periode 3 (Rabu-Minggu) dan seterusnya. Berdasarkan persamaan (1), (2) dan (3) dapat disusun model program linier bahasa pemograman dengan menggunakan software Lindo untuk periode 6 (Sabtu-Rabu) adalah sebagai berikut.

MAX $6 \mathrm{X} 11+4 \mathrm{X} 12+2 \mathrm{X} 13+6 \mathrm{X} 14+4 \mathrm{X} 15+10 \mathrm{X} 21+10 \mathrm{X} 22+10 \mathrm{X} 23+10 \mathrm{X} 24+10 \mathrm{X} 25+6 \mathrm{X} 31+$ $4 \mathrm{X} 32+2 \mathrm{X} 33+6 \mathrm{X} 34+4 \mathrm{X} 35+10 \mathrm{X} 41+6 \mathrm{X} 42+2 \mathrm{X} 43+10 \mathrm{X} 44+6 \mathrm{X} 45+6 \mathrm{X} 51+6 \mathrm{X} 52+6 \mathrm{X} 53+6 \mathrm{X} 54+$ $6 \mathrm{X} 55+6 \mathrm{X} 61+8 \mathrm{X} 62+10 \mathrm{X} 63+6 \mathrm{X} 64+8 \mathrm{X} 65+6 \mathrm{X} 71+6 \mathrm{X} 72+6 \mathrm{X} 73+6 \mathrm{X} 74+6 \mathrm{X} 75+6 \mathrm{X} 81+8 \mathrm{X} 82+$ $10 X 83+6 X 84+8 X 85+6 X 91+4 X 92+2 X 93+6 X 94+4 X 95+10 X 101+6 X 102+2 X 103+10 X 104+$ $6 \times 105$

\section{SUBJECT TO}

$$
\begin{aligned}
& X 11+X 12+X 13+X 14+X 15=1 \\
& X 21+X 22+X 23+X 24+X 25=1 \\
& X 31+X 32+X 33+X 34+X 35=1 \\
& X 41+X 42+X 43+X 44+X 45=1 \\
& X 51+X 52+X 53+X 54+X 55=1 \\
& X 61+X 62+X 63+X 64+X 65=1 \\
& X 71+X 72+X 73+X 74+X 75=1 \\
& X 81+X 82+X 83+X 84+X 85=1 \\
& X 91+X 92+X 93+X 94+X 95=1 \\
& X 101+X 102+X 103+X 104+X 105=1 \\
& X 11+X 21+X 31+X 41+X 51+X 61+X 71+X 81+X 91+X 101>=2 \\
& X 12+X 22+X 32+X 42+X 52+X 62+X 72+X 82+X 92+X 102>=2 \\
& X 13+X 23+X 33+X 43+X 53+X 63+X 73+X 83+X 93+X 103>=2 \\
& X 14+X 24+X 34+X 44+X 54+X 64+X 74+X 84+X 94+X 104>=2 \\
& X 15+X 25+X 35+X 45+X 55+X 65+X 75+X 85+X 95+X 105>=2
\end{aligned}
$$


Model program linier untuk periode-periode jadwal selanjutnya sama dengan model matematis di atas, yang membedakan hanya pada nilai bobot kesukaan liburnya saja. Selanjutnya model program linier tiap periode jadwal yang telah disusun tersebut dilanjutkan dengan menambahkan keterangan 'INTE' untuk setiap variabel keputusan agar nilainya bernilai 0 atau 1 [13]. Selanjutnya pilih tool "Solve" untuk menjalankan menyelesaikan model program linier tersebut, sehingga diperoleh hasil menggunakan software Lindo untuk periode 6 seperti pada Gambar 1, berikut:

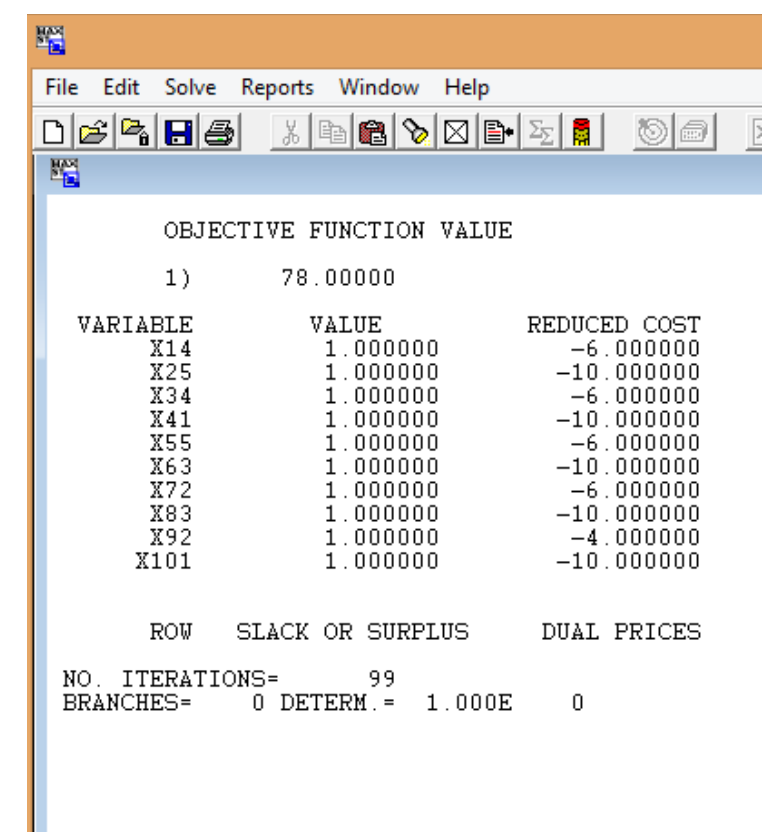

Gambar 1. Solusi Optimal Program Linier Integer 0-1

Berdasarkan Gambar 1, diperoleh total bobot kesukaan libur optimal pada periode 6 adalah 78, dimana $X_{14}=X_{25}=X_{34}=X_{41}=X_{55}=X_{63}=X_{72}=X_{83}=X_{92}=X_{101}=1$ sedangkan untuk $X_{\mathrm{ik}}$ yang lain bernilai nol, sehingga solusi tersebut dapat diimplentasikan ke kondisi permasalahan real-nya yaitu keputusan petugas dalam memilih tipe jadwal pada periode 6 disajikan pada Tabel 4. Penelitian lainya menggunakan metode program linier dan diselesaikan menggunakan software Lindo telah dilakukan oleh Leatemia [13]. Sedangkan penjelaskan perhitungan menyelesaikan permasalahan program linier integer $0-1$ secara manual pernah dijelaskan oleh [15], [16], [17], [18] serta [19].

Tabel 4. Keputusan Memilih Tipe Jadwal Periode 6 (Rabu-Sabtu)

\begin{tabular}{|clllcll|}
\hline \multirow{2}{*}{ No } & \multicolumn{1}{c}{ Nama } & $\mathbf{1}$ & $\mathbf{2}$ & $\mathbf{3}$ & $\mathbf{4}$ & $\mathbf{5}$ \\
\cline { 2 - 7 } & & $\mathbf{1}$ & 0 & 0 & 1 & 0 \\
1. & Drs. M. Nukman & 0 & 0 & 0 & 0 & 1 \\
2. & M. Ramli Saputra & 0 & 0 & 0 & 1 & 0 \\
3. & Abadiono & 1 & 0 & 0 & 0 & 0 \\
4. & Hamzah & 0 & 0 & 0 & 0 & 1 \\
5. & Abdurrachman & 0 & 0 & 1 & 0 & 0 \\
6. & Ryan Soneta & 0 & 1 & 0 & 0 & 0 \\
7. & Juli Fitriadi, S. Ap & 0 & 0 & 1 & 0 & 0 \\
8. & Nahudidin & 0 & 1 & 0 & 0 & 0 \\
9. & Hermansyah & 1 & 0 & 0 & 0 & 0 \\
10. & Kaharudin & & & & & \\
\hline
\end{tabular}

Data Tabel 4 menjelaskan bahwa anggota Satpol PP atas nama Drs. M. Nukman memilih tipe jadwal 2 pada periode 6 (Sabtu-Rabu). Dengan cara yang sama di atas maka dapat disusun tipe jadwal untuk periodeperiode yang lainnya. Setelah diperoleh hasil keputusan pemilihan tipe jadwal untuk periode-periode yang lain maka dapat disusun draf jadwal shift dinas anggota Satpol PP Bidang KIBUM kelompok I. Misalkan 
jadwal ini diberlakukan pertama kali pada bulan September 2018, maka periode jadwal yang digunakan adalah periode 6 (Sabtu-Rabu), periode 4 (Kamis-Senin), periode 2 (Selasa-Sabtu), periode 7 (MingguKamis), periode 5 (Jumat-Selasa) dan periode 3 (Rabu-Minggu). Sehingga dapat disusun draf jadwal shift dinas anggota Satpol PP Bidang KIBUM kelompok I yang disajikan pada Tabel 5 sebagai berikut.

Tabel 5. Jadwal Shift Piket Anggota Satpol PP Bidang KIBUM Kelompok I Bulan September 2018

\begin{tabular}{|c|c|c|c|c|c|c|c|c|c|c|c|c|c|c|c|c|c|c|c|c|c|c|c|c|c|c|c|c|c|c|c|}
\hline \multirow{3}{*}{ No. } & \multirow{3}{*}{ Nama } & \multicolumn{30}{|c|}{ Hari dan Tanggal } \\
\hline & & $\underset{\ddot{z}}{\ddot{z}}$ & 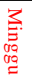 & $\begin{array}{l}\widetilde{\Xi} \\
\text { E. }\end{array}$ & 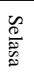 & $\begin{array}{l}\underset{\tilde{\sigma}}{\Xi} \\
\stackrel{\sigma}{\sigma}\end{array}$ & $\begin{array}{l}\text { 줄. } \\
\text { 害. }\end{array}$ & $\begin{array}{l}\breve{\Xi} \\
\stackrel{\Xi}{ٍ}\end{array}$ & $\begin{array}{l}\mathscr{\tilde { \sigma }} \\
\tilde{\Xi}\end{array}$ & 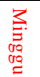 & $\begin{array}{l}\mathscr{\varrho} \\
\stackrel{\Xi}{\Xi}\end{array}$ & 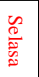 & 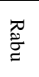 & $\begin{array}{l}\text { त्. } \\
\text { 宸. }\end{array}$ & $\begin{array}{l}\breve{E} \\
\stackrel{\Xi}{ٍ}\end{array}$ & $\begin{array}{l}\mathscr{\tilde { E }} \\
\stackrel{\vec{E}}{ }\end{array}$ & 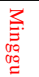 & $\begin{array}{l}\mathscr{\Phi} \\
\stackrel{\Xi}{\Xi} .\end{array}$ & \begin{tabular}{l}
$\mathscr{\mathscr { D }}$ \\
$\frac{\tilde{D}}{\tilde{W}}$ \\
\multirow{2}{*}{}
\end{tabular} & 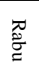 & 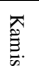 & 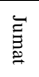 & $\begin{array}{l}\mathscr{\tilde { \sigma }} \\
\vec{E}\end{array}$ & 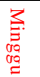 & $\begin{array}{l}\mathscr{\varrho} \\
\stackrel{0}{E} .\end{array}$ & 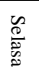 & $\begin{array}{l}\underset{\tilde{\sigma}}{\Xi} \\
\stackrel{\Xi}{\Xi}\end{array}$ & $\begin{array}{l}\text { T. } \\
\text { 密. }\end{array}$ & $\vec{\Xi}$ & $\begin{array}{l}\mathscr{\ddot { \Xi }} \\
\stackrel{\tilde{E}}{E}\end{array}$ & 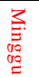 \\
\hline & & 1 & 2 & 3 & 4 & 5 & 6 & 7 & 8 & 9 & 10 & 11 & 12 & 13 & 14 & 15 & 16 & 17 & 18 & 19 & 20 & 21 & 22 & 23 & 24 & 25 & 26 & 27 & 28 & 29 & 30 \\
\hline 1 & Drs. M. Nukman & $\mathrm{S}$ & $P$ & $\mathrm{M}$ & $\mathrm{L}$ & $\mathrm{L}$ & $\mathrm{M}$ & $\mathrm{L}$ & $\mathrm{L}$ & $\mathrm{s}$ & $\mathrm{P}$ & $\mathrm{S}$ & $\mathrm{P}$ & $\mathrm{M}$ & $\mathrm{L}$ & $\mathrm{L}$ & $\mathrm{P}$ & $\mathrm{M}$ & $\mathrm{L}$ & $\mathrm{L}$ & $\mathrm{S}$ & $\mathrm{L}$ & $\mathrm{L}$ & $\mathrm{S}$ & $\mathrm{P}$ & $\mathrm{M}$ & $\mathrm{L}$ & $\mathrm{S}$ & $\mathrm{P}$ & $\mathrm{M}$ & $\mathrm{L}$ \\
\hline 2 & M.RamliSaputra & $\mathrm{L}$ & $\mathrm{S}$ & $P$ & $\mathrm{M}$ & $\mathrm{L}$ & $\mathrm{S}$ & $\mathrm{P}$ & $\mathrm{M}$ & $\mathrm{L}$ & $\mathrm{L}$ & $\mathrm{L}$ & $\mathrm{S}$ & $\mathrm{P}$ & $\mathrm{M}$ & $\mathrm{L}$ & $\mathrm{L}$ & $\mathrm{S}$ & $\mathrm{P}$ & $\mathrm{M}$ & $\mathrm{L}$ & $\mathrm{P}$ & $\mathrm{M}$ & $\mathrm{L}$ & $\mathrm{L}$ & $\mathrm{S}$ & $\mathrm{L}$ & $\mathrm{S}$ & $\mathrm{P}$ & $\mathrm{M}$ & $\mathrm{L}$ \\
\hline 3 & Abadiono & $\mathrm{S}$ & $\mathrm{P}$ & $\mathrm{M}$ & $\mathrm{L}$ & $\mathrm{L}$ & $\mathrm{L}$ & $\mathrm{L}$ & $\mathrm{S}$ & $\mathrm{P}$ & $\mathrm{M}$ & $\mathrm{L}$ & $\mathrm{L}$ & $\mathrm{S}$ & $\mathrm{P}$ & $\mathrm{M}$ & $\mathrm{S}$ & $\mathrm{P}$ & $\mathrm{M}$ & $\mathrm{L}$ & $\mathrm{L}$ & $\mathrm{L}$ & $\mathrm{S}$ & $\mathrm{P}$ & $\mathrm{M}$ & $\mathrm{L}$ & $\mathrm{M}$ & $\mathrm{L}$ & $\mathrm{L}$ & $\mathrm{S}$ & $\mathrm{P}$ \\
\hline 4 & Hamzah & $\mathrm{P}$ & $\mathrm{M}$ & $\mathrm{L}$ & $\mathrm{L}$ & $\mathrm{S}$ & $\mathrm{L}$ & $\mathrm{S}$ & $\mathrm{P}$ & $\mathrm{M}$ & $\mathrm{L}$ & $\mathrm{L}$ & $\mathrm{L}$ & $\mathrm{S}$ & $\mathrm{P}$ & $\mathrm{M}$ & $\mathrm{L}$ & $\mathrm{L}$ & $\mathrm{S}$ & $\mathrm{P}$ & $\mathrm{M}$ & $\mathrm{S}$ & $\mathrm{P}$ & $\mathrm{M}$ & $\mathrm{L}$ & $\mathrm{L}$ & $\mathrm{L}$ & $\mathrm{L}$ & $\mathrm{S}$ & $P$ & $\mathrm{M}$ \\
\hline 5 & Abdurrachman & $\mathrm{L}$ & $\mathrm{S}$ & $\mathrm{P}$ & $\mathrm{M}$ & $\mathrm{L}$ & $\mathrm{P}$ & $\mathrm{M}$ & $\mathrm{L}$ & $\mathrm{L}$ & $\mathrm{S}$ & $\mathrm{L}$ & $\mathrm{S}$ & $\mathrm{P}$ & $\mathrm{M}$ & $\mathrm{L}$ & $\mathrm{L}$ & $\mathrm{S}$ & $\mathrm{P}$ & $\mathrm{M}$ & $\mathrm{L}$ & $\mathrm{L}$ & $\mathrm{L}$ & $\mathrm{S}$ & $\mathrm{P}$ & $\mathrm{M}$ & $\mathrm{P}$ & $\mathrm{M}$ & $\mathrm{L}$ & $\mathrm{L}$ & $\mathrm{S}$ \\
\hline 6 & Ryan Soneta & $\mathrm{L}$ & $\mathrm{L}$ & $\mathrm{S}$ & $\mathrm{P}$ & $\mathrm{M}$ & $\mathrm{L}$ & $\mathrm{L}$ & $\mathrm{S}$ & $P$ & $\mathrm{M}$ & $P$ & $\mathrm{M}$ & $\mathrm{L}$ & $\mathrm{L}$ & $\mathrm{S}$ & $\mathrm{S}$ & $\mathrm{P}$ & $\mathrm{M}$ & $\mathrm{L}$ & $\mathrm{L}$ & $\mathrm{L}$ & $\mathrm{S}$ & $\mathrm{P}$ & $\mathrm{M}$ & $\mathrm{L}$ & $\mathrm{M}$ & $\mathrm{L}$ & $\mathrm{L}$ & $\mathrm{S}$ & $\mathrm{P}$ \\
\hline 7 & Juli Fitriadi,S.AP & $\mathrm{M}$ & $\mathrm{L}$ & $\begin{array}{l}\mathrm{L} \\
\end{array}$ & $\mathrm{S}$ & $P$ & $\mathrm{M}$ & $\mathrm{L}$ & $\mathrm{L}$ & $\mathrm{S}$ & $P$ & $\mathrm{~S}$ & $P$ & $\mathrm{M}$ & $\mathrm{L}$ & $\mathrm{L}$ & $P$ & $\mathrm{M}$ & $\mathrm{L}$ & $\mathrm{L}$ & $\mathrm{S}$ & $\mathrm{M}$ & $\mathrm{L}$ & $\mathrm{L}$ & $\mathrm{S}$ & $P$ & $P$ & $\mathrm{M}$ & $\mathrm{L}$ & $\mathrm{L}$ & $\mathrm{S}$ \\
\hline 8 & Nahnuddin & $\mathrm{L}$ & $\mathrm{L}$ & $\mathrm{S}$ & $P$ & $\mathrm{M}$ & $\mathrm{P}$ & $\mathrm{M}$ & $\mathrm{L}$ & $\mathrm{L}$ & $\mathrm{S}$ & $\mathrm{L}$ & $\mathrm{S}$ & $\mathrm{P}$ & $\mathrm{M}$ & $\mathrm{L}$ & $\mathrm{L}$ & $\mathrm{L}$ & $\mathrm{S}$ & $\mathrm{P}$ & $\mathrm{M}$ & $\mathrm{M}$ & $\mathrm{L}$ & $\mathrm{L}$ & $\mathrm{S}$ & $\mathrm{P}$ & $\mathrm{S}$ & $\mathrm{P}$ & $\mathrm{M}$ & $\mathrm{L}$ & $\mathrm{L}$ \\
\hline 9 & Hermansyah & $\mathrm{M}$ & $\mathrm{L}$ & $\mathrm{L}$ & $\mathrm{S}$ & $\mathrm{P}$ & $\mathrm{S}$ & $\mathrm{P}$ & $\mathrm{M}$ & $\mathrm{L}$ & $\mathrm{L}$ & $\mathrm{L}$ & $\mathrm{L}$ & $\mathrm{S}$ & $\mathrm{P}$ & $\mathrm{M}$ & $\mathrm{M}$ & $\mathrm{L}$ & $\mathrm{L}$ & $\mathrm{S}$ & $\mathrm{P}$ & $\mathrm{P}$ & $\mathrm{M}$ & $\mathrm{L}$ & $\mathrm{L}$ & $\mathrm{S}$ & $\mathrm{S}$ & $P$ & $\mathrm{M}$ & $\mathrm{L}$ & $\mathrm{L}$ \\
\hline 10 & Kaharudin & $\mathrm{P}$ & $\mathrm{M}$ & $\mathrm{L}$ & $\mathrm{L}$ & $\mathrm{S}$ & $\mathrm{L}$ & $\mathrm{S}$ & $\mathrm{P}$ & $\mathrm{M}$ & $\mathrm{L}$ & $\mathrm{M}$ & $\mathrm{L}$ & $\mathrm{L}$ & $\mathrm{S}$ & $\mathrm{P}$ & $\mathrm{M}$ & $\mathrm{L}$ & $\mathrm{L}$ & $\mathrm{S}$ & $\mathrm{P}$ & $\mathrm{S}$ & $\mathrm{P}$ & $\mathrm{M}$ & $\mathrm{L}$ & $\mathrm{L}$ & $\mathrm{L}$ & $\mathrm{L}$ & $\mathrm{S}$ & $\mathrm{P}$ & $\mathrm{M}$ \\
\hline
\end{tabular}

Keterangan:
P : Pagi (07.30-18.30);
S : Siaga (07.30-16.00);
M: Malam (18.30-07.30);
L : Libur;

Perbandingan jadwal usulan dengan jadwal yang Selama ini digunakan oleh anggota Satpol PP:

- Converage (perbandingan jumlah pengunjung dan Satpol PP); Kedua penjadwalan yaitu penjadwalan real dan usulan masih kurang memenuhi aspek ini karena perbandingan jumlah pengunjung yang berkunjung ke Pemerintahan Daerah dengan anggota Satpol PP kurang sesuai dengan seharusnya.

- Quality (kualitas); Penjadwalan usulan lebih dapat memenuhi aspek ini bila dibandingkan dengan penjadwalan real. Karena pada penjadwalan usulan ini, anggota Satpol PP dijadwalkan berdasarkan bobot preferensi yang mereka berikan terhadap hari libur yang mereka sukai.

- Stability (Kesetabilan); Kedua jadwal sama-sama menggunakan penjadwalan siklis. Sehingga jadwal dapat lebih stabil terhadap sejumlah faktor misalnya kebijaksanaan libur.

- Flexibility (Fleksibel); Salah satu kelemahan dari metode penjadwalan siklis adalah tidak fleksibel karena itu kedua jadwal mengalami kesulitan bila terjadi sejumlah perubahan-perubahan yang mendasar, misalnya ada anggota Satpol PP yang secara mendadak berhalangan hadir.

- Fairness (Keadilan); Penjadwalan usulan dapat lebih memenuhi aspek ini karena jadwal yang dihasilkan memberikan rasa keadilan yang sama bagi seluruh anggota Satpol PP yang ditugaskan.

\section{KESIMPULAN}

1. Jadwal usulan menghasilkan jadwal yang mampu mengoptimalkan bobot preferensi kesukaan libur dari setiap anggota Satpol PP.

2. Hasil perbandingan antara kedua jadwal bahwa terdapat sejumlah aspek penjadwalan seperti kualitas, stabilitas dan keadilan (fairness) penjadwalan yang dilakukan dalam penelitian ini (usulan) lebih dominan. Sedangkan pada dua aspek lain yaitu converage dan fleksibilitas kedua penjadwalan memiliki perbandingan yang hampir sama dimana converage kedua penjadwalan yaitu penjadwalan real dan usulan masih kurang memenuhi.

\section{UCAPAN TERIMA KASIH}

Peneliti mengucapkan terima kasih kepada anggota Satpol PP di Kota Sumbawa Besar yang telah besedia meluangkan waktunya untuk mengisi kuesioner dari penelitian ini. 


\section{DAFTAR PUSTAKA}

[1] H. Susiani, "PENEGAKAN PERATURAN DAERAH ( Studi Penertiban PKL Di Bandar Lampung ),” Fiat Justisia J. Law, vol. 10, no. 1, pp. 101-124, 2016.

[2] K. Hermanto, Marwan, and M. U. Romdhini, "Pengoptimuman Penjadwalan Perawat Pada Intalasi Ruang Inap RSU Propinsi NTB," Beta, vol. 4, no. 1, pp. 68-86, 2011.

[3] K. Hermanto, "Penjadwalan Perawat Usulan Menggunakan Pemrograman Integer Nol-Satu (Studi Kasus: Instalasi Ruang Inap Angrek RSU Propinsi NTB)," Tambora, vol. 2, no. 1, pp. 89-111, 2017.

[4] M. Widyastiti and Lestari Dwi Asih, “Optimalisasi Penjadwalan Perawat Siklik Menggunakan Integer Non-Linear Programming di Rumah Sakit Sehat Terpadu Dompet Dhuafa Parung, Bogor,” Ekologia, vol. 15, no. 1, pp. 3541, 2015.

[5] P. Fattahi, F. Jolai, and J. Arkat, "Flexible job shop scheduling with overlapping in operations," Appl. Math. Model., vol. 33, no. 7, pp. 3076-3087, 2009, doi: 10.1016/j.apm.2008.10.029.

[6] L. Lin and H. Jia-zhen, "Multi-Objective Flexible Job-Shop Scheduling Problem in Steel Tubes Production,” Syst. Eng. - Theory Pract., vol. 29, no. 8, pp. 117-126, 2009, doi: 10.1016/S1874-8651(10)60063-4.

[7] E. Moradi, S. M. T. F. Ghomi, and M. Zandieh, "Expert Systems with Applications Bi-objective optimization research on integrated fixed time interval preventive maintenance and production for scheduling flexible job-shop problem," Expert Syst. Appl., vol. 38, no. 6, pp. 7169-7178, 2011, doi: 10.1016/j.eswa.2010.12.043.

[8] D. Chaerani and S. P. Dewanto, "Model Optimisasi Linier Integer untuk Masalah Pemilihan Media Periklanan dengan menggunakan Pendekatan Konsep Set Covering," vol. 9, no. 1, pp. 61-74, 2013.

[9] P. C. Pop, I. Kara, and A. H. Marc, "New mathematical models of the generalized vehicle routing problem and extensions," Appl. Math. Model., vol. 36, no. 1, pp. 97-107, 2012, doi: 10.1016/j.apm.2011.05.037.

[10] K. Hermanto, "Model Matematika Generalize Vehicle Routing Problem dan Eksistensinya Studi Kasus: PT. Papertech Indonesia Unit II Magelang,” Universitas Gadjah Mada, 2015.

[11] C. Lu, R. Zhang, and S. Liu, "A 0-1 integer programming model and solving strategies for the slab storage problem," vol. 7543, no. February, pp. 0-11, 2016, doi: 10.1080/00207543.2015.1076949.

[12] S. Basriati, "Integer Linear Programming dengan Pendekatan Metode Cutting Plane dan Branch and Bound untuk Optimasi Produksi Tahu," J. Sains Mat. dan Stat., vol. 4, no. 2, pp. 43-66, 2018, doi: 10.1007/978-3-319-63976$5 \_4$.

[13] R. Zulmaulida and E. Saputra, "Pengembangan Bahan Ajar Program Linear Berbantuan Lindo Software," Infin. J., vol. 3, no. 2, p. 189, 2014, doi: 10.22460/infinity.v3i2.63.

[14] K. E. Leatemia, “Optimasi Biaya Dan Durasi Proyek Menggunakan Program Lindo ( Studi Kasus : Pembangunan Dermaga Penyeberangan Salakan Tahap II )," vol. 1, no. 4, pp. 226-232, 2013.

[15] H. A. T. Taha, Riset Operasi: Suatu Pengantar, Lima. Grogol: Binarupa Aksara, 1996.

[16] J. J. Siang, Riset Operasi dalam Pendekatan Algoritmis, 2nd ed. Yogyakarta: C.V Andi Offset, 2014.

[17] E. Susanti, E. S. Cahyono, and O. Dwipurwani, "Optimasi Kendaraan Pengangkut Sampah di Kecamatan Kertapati Menggunakan Pemrograman Bilangan Bulat Biner 0 dan 1," J. Mat., vol. 6, no. 2, p. 79, 2016, doi: 10.24843/jmat.2016.v06.i02.p70.

[18] R. Arefin, T. Hossain, and A. Islam, “Additive Algorithm for Solving 0-1 Integer Linear Fractional Programming Problem,” Dhaka Univ. J. Sci., vol. 61, no. 2, pp. 173-178, 2013.

[19] A. Freville and G. Plateau, "Heuristics and reduction methods for multiple constraints 0-1 linear programming problems," Eur. J. Oper. Researc, vol. 24, pp. 206-215, 1986. 
